\title{
How to Challenge University Students to Work on Integrated Reporting and Integrated Reporting Assurance
}

\author{
Maria Albertina Barreiro Rodrigues ${ }^{1,2, *(\mathbb{D})}$ and Ana Isabel Morais ${ }^{3}$ \\ 1 School of Business and Social Sciences, Universidade Europeia, 1500-210 Lisbon, Portugal \\ 2 Lisbon Accounting and Business School, ISCAL, IPL, 1069-035 Lisbon, Portugal \\ 3 Advance/CSG, ISEG-Lisbon School of Economics \& Management, Universidade de Lisboa, \\ 1200-781 Lisbon, Portugal; anamorais@iseg.ulisboa.pt \\ * Correspondence: mariabrodrigues@netcabo.pt
}

check for updates

Citation: Rodrigues, M.A.B.; Morais, A.I. How to Challenge University Students to Work on Integrated Reporting and Integrated Reporting Assurance. Sustainability 2021, 13, 10761. https://doi.org/10.3390/ su131910761

Academic Editors: Aurélien Decamps, Benoit Martimort-Asso and Carine Royer

Received: 30 July 2021

Accepted: 23 September 2021

Published: 28 September 2021

Publisher's Note: MDPI stays neutral with regard to jurisdictional claims in published maps and institutional affiliations.

Copyright: (c) 2021 by the authors. Licensee MDPI, Basel, Switzerland. This article is an open access article distributed under the terms and conditions of the Creative Commons Attribution (CC BY) license (https:// creativecommons.org/licenses/by/ $4.0 /)$.

\begin{abstract}
Since the beginning of the twenty-first century, society has become more sensitive to sustainability and to the consequences of companies' activities. Furthermore, the demands for change in corporate reporting have led to the emergence of integrated reporting (IR) and an increase in the disclosure of nonfinancial information assurance to ensure the compliance of integrated information. Universities need to embrace this challenge and be part of this change. This research's goal is to enhance the diffusion of IR and integrated reporting assurance (IRA) in the curricula of universities by presenting a tool for professors and universities to help introduce the subjects in higher education institutions. The methodological approach develops a theoretical analysis of published IR and IRA articles related to education, to create a presentation of the challenge learning method (CLM) for professors and high education institutions to develop the subject of IRA to challenge students. Considering teaching experience as a value-added component to research the proposed method comes from the teaching experience of the authors. The result consists of a method that can increase accounting academics knowledge of IR and IRA and motivate students to study these emerging accounting practices. This study contributes to the extant literature on IR, IRA and Education that is scarce, the use of appropriate teaching methods to IR and IRA, and the dissemination of IR and IRA in education by providing a better connection between the universities and the best practices of corporate reporting and auditing. This study leads to an increase in the connection among higher education institutions, professors, students, practitioners, auditors, regulators, standard setters, and society in general.
\end{abstract}

Keywords: integrated reporting; sustainability reporting; integrated reporting assurance; education; challenge learning method

\section{Introduction}

Society is evolving and becoming more sensitive to sustainability and to the consequences of companies' activities [1]. In the beginning of the twenty-first century, there was a distinct increase in society's environmental conscience that was reflected in the multiple initiatives related to climate change and sustainable development. Further, financial investors based their investment decisions on Environmental, Social, and Governmental (ESG) parameters that embraced sustainability factors as the basis to identify companies with superior business models [2,3]. The United Nations established its sustainable development goals in 2015 with the 2030 Agenda for Sustainable Development [4]. The movement "Fridays For Future" is a school climate strike movement inspired by Greta Thunberg $[5,6]$ that has registered an increasing number of young climate activists.

Along with this activism, integrated reporting (IR) has emerged to meet the demands for change in corporate reporting and an increase in the mandatory financial reporting of sustainable information by companies [7]. This new corporate reporting model looks at the activities developed by companies in a holistic way that is based on integrated 
thinking and discloses financial and nonfinancial information. In order to ensure the compliance of integrated information and to increase legitimacy and sustainability, there is an increase in the disclosure of nonfinancial information assurance [8-11]. The subject of integrated reporting assurance (IRA) is emerging and has growing relevance in academic research [12-14]. The International Integrated Reporting Council (IIRC) and International Federation of Accountants (IFAC), started a discussion in 2020 on the progress of IRA, and the IIRC published two studies in 2015 and 2014 that approach the subject of assurance [15-17]. Higher education institutions need to be part of this change and to embrace the challenge of leading this activism, both in relation to corporate reporting and in relation to the concerns of young people who will be attending the universities in the near future.

Universities play a strategic role in the adoption and diffusion of IR, both by providing relevant research and by teaching future accounting professionals [18]. The widespread adoption of IR requires significant development in practitioners and in the accounting curricula at universities $[19,20]$. Considering this need, academics must hold this new subject to enhance accounting education and improve the connection between universities and the skills and knowledge required by employers [21]. According to Adhariani e de Villiers [20], accounting academics have no better knowledge of IR than other stakeholder classes; therefore, it is necessary to provide specified learning models to teach IR and IRA. Furthermore, accounting and auditing students need to be trained and exposed to different types of reporting frameworks and assurance services [22].

The literature about teaching IR and IRA is scarce, and there are few instructional cases proposed. Brown and Kohlbeck [23] propose an instructional case about the provision of assurance to nonfinancial sustainability reporting that is designed for upper-level undergraduate and graduate auditing courses. Instead of using problem-based learning, our study uses the basis of challenge-based learning, which combines the best aspects of problem-based learning by focusing on the problems faced in the real world. A unique feature of challenge-based learning is that problems are tied to an idea from a global perspective [24]; in this case, the assurance of integrated report. Although this method is scarcely used in the research on IR, we argue that it is well-suited to teaching IRA. Further, this study presents an assessment model that can be used to evaluate the success of CLM.

Based on the identified gap in the literature about learning practices for IRA that creates the opportunity to develop this study, the motivation and relevance of this paper is to enhance the diffusion of IR and IRA in the curricula of universities by presenting a guide or a tool for professors and universities to help introduce the subjects to the undergraduate and post-graduate levels.

In this study, we address three research questions:

RQ1: What are the learning practices used to teach IR and IRA?

RQ2: How can the challenge learning method be used to teach IRA?

RQ3: What indicators can be used to assess the performance of the challenge learning method when it is applied to IRA?

The methodological approach develops a theoretical analysis of published IR and IRA articles related to education, in order to develop and create a presentation of the challenge learning method (CLM) for professors and higher education institutions to develop the subject of IR and IRA to challenge students. Based on Feldon et al., teaching experience is a value-added component to research and may contribute to a substantive increase in essential research skills [25], so the proposed method comes from the teaching experience of the authors [26].

The result of the study is a method that can increase accounting academics knowledge of IR and IRA and motivate students to study these emerging accounting practices. It provides avenues for improvement in the practice of teaching the IRA at universities at the undergraduate and post-graduate levels.

This study has several contributions, the first being its contribution to the extant literature on IR, IRA, and Education which is scarce. Second, our research contributes to 
the use of appropriate teaching methods of IR and IRA. Third, our study contributes to the dissemination of IR and IRA in education by providing a better connection between universities and the best practices of corporate reporting and auditing. Therefore, this study leads to an increase in the connection among higher education institutions, professors, students, practitioners, auditors, regulators, standard setters, and society in general.

The theoretical implications of this study consist of the identification of teaching methodologies used for the teaching of sustainability and the presentation of a proposal for a higher education methodology appropriate to GFRI. The practical implication is related to the implementation of the transmission of knowledge in higher education.

This study has the following structure: In Section 2, we review the literature. Then, in Section 3, we present the method, and in Section 4 we present the application of CLM. Section 5 is a discussion of the results, and Section 6 concludes.

\section{Literature Review}

In recent years, we have witnessed an increase in the number of papers published about IR. Papers about external reporting [27], accountability and governance [28], management control and strategy [29], audit and assurance [30], and performance measurement [31,32], show the relevance of the field of IR.

We have identified four theories that are used more often in relation to IR, Assurance, and Education: agency theory, institutional theory, legitimacy theory, and stakeholder theory. According to agency theory, assurance intends to reduce asymmetry between principals and managers by increasing the accuracy, completeness, and reliability of disclosed information and enhances an outsider's perception of the trustworthiness of the information; therefore, auditors play a role in the increase of transparency trough external assurance [33-36]. The central thesis based on agency theory is that independent audits detect or even reduce, fraudulent reporting practices [37]. Wang, Zhou, and Wang conclude that the rise in voluntary sustainability reporting challenges the usefulness of agency theory in explaining the motivation for CSR activities and disclosures, once CSR reports are aimed not just to shareholders but to a wider range of stakeholders [38].

Institutional theory perspective focuses on the influence of political, social, and economic systems on company behavior and legitimacy [39] Corporate activities do not necessarily follow a business rationale but instead answer to the institutionalized expectations of the environment [40], therefore suggesting a convergence among firms with similar resources and capabilities and exposed to a common industry environment [41]. Wild and van Staden [42], found that institutional factors influence the contents of the reports and foment the early IR. Assurance appears because of coercive, mimetic, normative pressures, and auditors employ normative and/or coercive pressures [33]. Regulation on CSR reporting determines the institutional structures, playing an important role in the development of CSR. EU policy, through directives or recommendations, exerts a pressure that is influencing the behavior of companies towards SR assurance [43].

Legitimacy theory suggests that no company has an inherent right to exist, but that any company is subject to a greater acceptance granted by society; corporations can only continue to exist and access the necessary resources, if the society in which they are based perceives the company to be operating with a value system that is adequate according to the society's own value system [38,40]. Corporate governance mechanisms, including auditing, aim to acquire organizational legitimacy, growth in the assurance market driven by assurance firms plugging the economic legitimization of sustainability report by focusing on the value of assurance as a control mechanism [37,44]. Companies need to disclose financial and non-financial data to report the performance of socially responsible companies, with the aim that such data may be verified externally [45]. Sustainability assurance allows both the internal and external legitimation of the responsible company's position to ensure higher transparency of the accounting system data and helping sustainable businesses to advance accounting for sustainable development [46]. 
According to stakeholder theory, management should operate the entity aware of the interests of various constituents. Managers need to recognize changes in the environment among internal and external stakeholders and satisfy a variety of stakeholders-e.g., government, local community employees, customers, and suppliers-who can influence firm outcomes. Otherwise non-financial stakeholders may withdraw their support for the firm if its focus is exclusively on shareholder value maximization $[40,44,47,48]$. Companies should act responsibly towards their stakeholders about the non-financial impacts of their operations, and legitimate company stakeholders require CSR disclosures to be independently assured [48,49]. Zyznarska-dworczak [50], have studied sustainability reporting development in the light of positive and normative accounting theories, concluding the need to ensure reliability in a way that accounting data can be validated internally and externally.

As mentioned, universities play an important and strategic role in the adoption and proliferation of IR, not only by providing relevant research but also by teaching future accounting professionals [18]. The IR and IRA need to be diffused among universities along with sustainability awareness. Because companies have changed their way of producing corporate reports and audits, the universities' approach to teaching has also had to evolve to follow the emerging trends in practice. Further, society is more aware of sustainability, so the survival of companies also depends on the judgement that society makes on their actions. Currently, a company can have a social contract, and if a company does not respect that contract, it may be forced to close. For example, if a company does not respect the regulation of pollution, public outcry may force a change in the situation or end its activity. The rise of society's awareness for new subjects is well demonstrated with the youth movement that is related to climate change. In light of this new generation's activism, universities have to adapt the subjects that are part of the curricula and their teaching methods. They need to challenge this generation instead of maintaining the status quo; they need to embrace the challenge and acknowledge these new concerns and attitudes by facing the problems and looking for a solution; to be part of the solution and not part of the problem. Universities must answer the challenge that the new generation presents to them and society.

The subject of education is not widespread in the papers related to IR and IRA. Nevertheless, there are some authors that mention the relationship between higher education and these subjects. According to Adhariani and de Villiers [20], accounting curriculums may have to change to respond to a move towards IR in order to properly educate current and future report preparers and stakeholders. To disseminate information regarding IR, there is a practical implication in universities with the need for changes in university curricula, training sessions, seminars, and conferences. The authors specifically mention that despite accounting curriculums already including IR in the ACCA and CIMA curriculum since 2014, higher education accounting curriculums in Indonesia do not mention IR yet. As highlighted by the authors, accounting academics who may be expected to be more knowledgeable had no better knowledge of IR than other stakeholder classes.

Perego, Kennedy, and Whiteman [18], mention that academics can make a relevant contribution to the dissemination of IR through education, in particular through executive education. However, the authors are also concerned that business schools are not currently providing sufficient educational programs on IR, and the result has been a need for educational programs to fill the void. Maroun [36] notes that the complexity of contemporary business models and the multidimensional focus of IR results in changes in the composition of audit teams. Furthermore, the application of an interpretive assurance model will require practitioners and auditing students to be trained extensively in qualitative analytical techniques. In another study, Maroun [22] specifies that in the education level, accounting and auditing students need to be exposed to different types of assurance services and reporting frameworks and not just to conventional financial statement audit. In that study, the author mentions that revisions to existing professional standards are necessary and that these should concentrate on providing guidance on how existing assurance frameworks 
can be used to deal with integrated report content. Therefore, accounting and auditing students will need to be trained in these reporting and assurance developments. According to Kräusche \& Pilz [51], universities have a special responsibility to society concerning sustainable development. It is vital how the subject of sustainability is penetrating the core businesses of teaching and research, and how the achievements are transferred to society. Simultaneously, universities are increasingly obliged to act and are called upon by the university members and stakeholders from society to make an active contribution to sustainable development and a fair coexistence. The authors also accentuate that the responsibility of education for sustainable development, as one of the basic tasks, is also revealed in all 17 Sustainable Development Goals passed by the United Nations in 2015 [4].

Dumay and Adams [52] consider that one of the reasons why intellectual capital does not penetrate and proliferate in management practice is the discourse of academics. Also, the efforts to disseminate topics such as sustainability, sustainable development, social accounting, and environmental cost systems in accounting education seems to be uncoordinated and sporadic with space for improvement [53,54]. However, Lee, Birkey, and Patten [55] show that bringing sustainability issues to the accounting curriculum can lead to positive student outcomes in terms of attitude, perceived behavioral control, intentions, and behavior. But accounting departments need more efforts in terms of support, materials, and reward structures.

The adoption of IR has implications for the content and structure of accounting curricula and the way accounting must be taught. Owen [19] describes how the adoption of IR may require significant developments in a university's accounting curricula. Students must deal with more unstructured information from a diversity of sources to evaluate entities, and the focus must change from transactional to strategic, from short-term to longterm, and from a retrospective to a more prospective analysis that combines both qualitative and quantitative data. These new focuses, in addition to the resistance of faculty members, make it difficult to introduce IR to traditional accounting and finance curricula [56]. Wong, Pippin, Weber, and Bergner [57] find that less than $2 \%$ of US universities offer embedded or stand-alone accounting courses in IR and sustainability.

The learning practices of IR are also diverse: problem-based learning [58-60], projectbased learning $[53,61]$, and experiential learning $[55,62,63]$, among others. However, the norm continues to be a passive pedagogy through lecturing and problem solving on the blackboard.

Problem-based learning involves students in developing a solution to a problem or a case without a clear answer that structures and creates learning through the duration of the activity. Wyness and Dalton [60] evaluate the students' perceptions of problem-based learning in teaching sustainability, and they find that this pedagogy is adequate. Several studies present case-based learning to sustainability. Bouten and Hoozée [58] propose a post-graduate level case, based on a Belgium telecommunication company's reporting practices, to introduce the concepts of sustainability and IR. Stubbs and Cocklin [59] present a sustainability framework to promote the development of critical and reflective thinking and discussion among MBA students. Hardin et al. [64] present a case-based approach for sustainability education and argue that this pedagogy is not only relevant for higher education but also for continued learning. Finally, Brown and Kohlbeck [23] propose, as far as we know, the only instructional case about the provision of assurance on nonfinancial sustainability reporting that is oriented toward upper-level undergraduate and graduate auditing courses.

Another active pedagogy is project-based learning that involves students applying and developing theories, skills, and techniques to solve real world problems. Hazelton and Haigh [53] describe the implementation of two projects with the objective of incorporating principles of sustainable development into postgraduate accounting curricula. They use an action research method that creates changes by improving the experience of students.

Although these two pedagogies promote critical thinking, experiential learning takes it one step further by learning through experience. Contrary to the other two types of 
learning, experiential learning is based on a challenge. The experiential learning is the pedagogy for the challenge-based learning that is based on the constructivist theory, which implies that individuals are constructors of their own knowledge, originated by interacting with their social and cultural environment [65]. This theory suggests that students learn best when they construct knowledge through personal experience and knowledge, more than information about a topic, is a combination of skills, attitudes, and knowledge that allows students to understand or do something [66]. The challenge-based learning is defined as "a collaborative learning experience in which teachers and students work together to learn about compelling issues, propose solutions to real problems, and take action." [67] (p. 3). Sulkowski et al. [68] applied the experiential learning to MBA students through a pilot project in which students prepare a sustainability report. Collins and Kearins [62] present an experiential exercise of simulated stakeholders' negotiation about sustainability to promote the critical reflection on the part of students.

Some studies have found that the implementation of problem-based learning by using the system of learning by doing, with particular emphasis in the importance of questioning, may be the best way to achieve better learning in accounting [69,70]. But the action of doing so may not be enough to attract students' attention and to generate the desire to learn. The key to successful learning is the ability to think, instead of just doing. It is through the presentation of challenges that professors may help students to go from doing to thinking. If professors present challenges to students, they are motivated to question, to think, to observe, and to find a way to evolve. Also, in the current context, reality is changing quickly which means today's solution for one problem may not be valid tomorrow. By challenging students, professors are helping them to always look for the best solution and to pay attention to new possibilities. Unlike project-based learning, this method does not present the question to the students, instead the CLM requires the students to ask their own questions. This pedagogy is particularly suitable for teaching concepts when there are a set of possible choices with many dimensions to the skills and an expert may not make all the choices explicit, and when the knowledge is context-specific and the situation is new and uncertain $[63,71]$. For these reasons, the research has found that experiential learning is an adequate pedagogy for teaching sustainability and IR.

The need to find and develop learning methods to increase the diffusion of IR and IRA is justified through previous research stating that academics can make a relevant contribution to the dissemination of IR through education, business schools are not providing sufficient educational programs on IR, that there is a need for additional educational programs [18], and accounting curriculum may have to change in order to properly educate current and future report preparers and stakeholders in IR [20]. Furthermore, Adhariani and de Villiers [20] have found that accounting academics have no better knowledge of IR than other stakeholders, making it necessary to provide specified learning models to teach IR and IRA. On the other hand, accounting and auditing students need to be exposed and trained on different types of assurance services and reporting frameworks [22].

\section{Methodology}

As mentioned, the literature about teaching IR and IRA is uncommon and there are not many educational cases proposed. Brown and Kohlbeck [23] propose an educational case about the provision of assurance to sustainability reporting that is planned for auditing courses. Our study uses the bases of challenge-based learning, instead of using problembased learning. According to Johnson, Smith, Smythe, and Varon, a unique characteristic of challenge-based learning is that problems are linked from a global perspective to an idea [24]; in this case the integrated report assurance.

The gap in the literature about learning practices for IRA creates the opportunity to develop this study.

This study initially draws on academic insights and analysis from studies published on IRA, IR, and on education in journals listed in the Web of Science database. The methodological approach develops in two phases: the first is a theoretical analysis of 
published articles on IRA; and the second develops the basis for the presentation of the CLM.

In the first phase, we consulted the database of Web of Science and then conducted the following search: for the keywords of integrated reporting, assurance, and education, we found no articles; for the same keywords but placing integrated reporting and assurance in the topic, and education in all other lines, we found four articles. For just the keywords of integrated reporting and education in the topic line, we found twelve articles. For the keywords of integrated reporting and education, placing integrated reporting in the topic line and education in all other fields, we found 34 articles. This sample creation represents the initial phase of the study.

In the second phase, based on Feldon et al., considering that teaching experience can be taken as a factor that adds value to research and significantly impacts the development of essential research skills [25], the proposed method that comes from the teaching experience of the authors [26] has been developed and used to introduce IRA in the subjects studied mainly in accounting, auditing, and entrepreneurship. This study presents CLM basis, phases, and detailed development. Furthermore, developed and is presented in this study is an assessment model that may be used to evaluate the success of CLM.

\section{Challenge Learning Method: Method for Challenging Students to Develop the Subject of Integrated Reporting Assurance}

\subsection{Challenge Learning Method: The Basis for the Method}

The CLM is based on the presentation of disruptive examples to create reactions from the students to initiate debate. In this way, students can learn more. The basis is to challenge students to debate the situations and to find solutions.

While some studies consider that teaching experience may contribute to a substantive increase in essential research skills and that it is a value-added component to research [25], the proposed method, as presented by Creel and Paz [26], comes from the teaching experience of the authors in which we have presented IR and IRA to accounting, entrepreneurship, and auditing classes

\subsection{Challenge Learning Method CLM: The Phases of the Method}

As presented in Table 1, the proposed method comprises the introduction to the context and motivation with the presentation of the main background knowledge in the first phase. First, one situation is presented that should be a disruptive or provocative situation with the objective to generate interest from students so that they can initiate the debate. To make the link with IR, we use the example of the Spice Girls gender t-shirt, the Enron bankruptcy, and the Volkswagen crisis. 
Table 1. Steps of the Challenge Learning Method.

\begin{tabular}{|c|c|c|c|c|}
\hline Phase & Action Goal & Main Participant & Action Content & Detailed Description \\
\hline \multirow{6}{*}{1} & \multirow{6}{*}{$\begin{array}{l}\text { Context and } \\
\text { motivation }\end{array}$} & \multirow{6}{*}{ Professor } & \multirow{3}{*}{$\begin{array}{l}\text { Main background } \\
\text { knowledge }\end{array}$} & $\begin{array}{l}\text { Corporate Reporting objective: to give } \\
\text { useful information for stakeholders to } \\
\text { make their decisions }\end{array}$ \\
\hline & & & & $\begin{array}{l}\text { Corporate Reporting: Financial Reporting } \\
\text { and Non-Financial Reporting }\end{array}$ \\
\hline & & & & New paradigm in corporate reporting-IR \\
\hline & & & $\begin{array}{l}\text { Real situation: } \\
\text { Spice Girls Gender } \\
\text { T-shirt }\end{array}$ & $\begin{array}{l}\text { It should be a disruptive situation with } \\
\text { the objective to create the interest in } \\
\text { students so that they initiate the } \\
\text { discussion }\end{array}$ \\
\hline & & & $\begin{array}{l}\text { Real situation: } \\
2008 \text { financial } \\
\text { crises and Enron } \\
\text { bankruptcy }\end{array}$ & $\begin{array}{l}\text { To make the link with Corporate } \\
\text { Reporting evolution, it is presented the } \\
\text { example of the } 2008 \text { financial crises, for } \\
\text { instance, the Enron bankruptcy }\end{array}$ \\
\hline & & & $\begin{array}{l}\text { Real situation: } \\
\text { Volkswagen crisis }\end{array}$ & $\begin{array}{l}\text { To make the link with IR and assurance } \\
\text { needs, it is presented the example of } \\
\text { Volkswagen crisis }\end{array}$ \\
\hline 2 & Challenge & Student's & $\begin{array}{l}\text { Student's } \\
\text { discussion }\end{array}$ & $\begin{array}{l}\text { Discussion about the situations presented } \\
\text { before }\end{array}$ \\
\hline \multirow{7}{*}{3} & \multirow{7}{*}{ State of the art } & \multirow{7}{*}{ Professor } & \multirow{3}{*}{$\begin{array}{l}\text { Evolution on } \\
\text { corporate } \\
\text { reporting }\end{array}$} & Financial Report \\
\hline & & & & Non-Financial Report \\
\hline & & & & Integrated Reporting \\
\hline & & & \multirow{2}{*}{$\begin{array}{l}\text { Evolution on } \\
\text { assurance }\end{array}$} & Financial Audit \\
\hline & & & & Non-financial information assurance \\
\hline & & & IRA & Focus on the need for legitimacy \\
\hline & & & & Present the limitations of assurance \\
\hline \multirow{3}{*}{4} & \multirow{3}{*}{ Challenge } & \multirow{3}{*}{ Student's } & \multirow{3}{*}{$\begin{array}{l}\text { Student's } \\
\text { discussion }\end{array}$} & The value of assurance \\
\hline & & & & $\begin{array}{l}\text { Reasons for companies to disclose } \\
\text { independent assurance }\end{array}$ \\
\hline & & & & $\begin{array}{l}\text { Find and discuss the evolution on the } \\
\text { legislation }\end{array}$ \\
\hline \multirow{3}{*}{5} & \multirow{3}{*}{ Challenge } & \multirow{3}{*}{ Student's } & \multirow{3}{*}{$\begin{array}{l}\text { Student's } \\
\text { discussion }\end{array}$} & $\begin{array}{l}\text { Professional qualification to assure } \\
\text { corporate reports }\end{array}$ \\
\hline & & & & Assurance Standards \\
\hline & & & & Sustainability Reporting Guidelines \\
\hline 6 & Challenge & Student's & $\begin{array}{l}\text { Student's } \\
\text { discussion }\end{array}$ & $\begin{array}{l}\text { Critical evaluation on the subjects } \\
\text { presented }\end{array}$ \\
\hline 7 & Best practices & Professor & & $\begin{array}{l}\text { Presentation of examples and best } \\
\text { practices }\end{array}$ \\
\hline
\end{tabular}

After the presentation of the context, the students are presented with one of the challenges, which they are encouraged to discuss and to try to find solutions.

While discussing the subject, students are presented with the current evolution of corporate reporting, auditing, and assurance. For corporate reporting, we use the financial report, nonfinancial report, and IR. For auditing and assurance, we introduce the basis of financial auditing and nonfinancial information assurance. We also explain the trend in the convergence of the IRA with a focus on the need for legitimacy and its limitations. 
After this presentation, a discussion among students is encouraged with the presentation of a challenge where they are asked to find the added value of assurance despite said limitations and the reasons for disclosing independent assurance in the annual report. Further, they are encouraged to find and discuss the evolution of the legislation, for example, the UE Non-Financial Information Directive and the proposal from the European Parliament of the directive regarding corporate sustainability reporting. With the focus on assurance, the students are then challenged to find and discuss the professional qualifications needed to assure corporate reports and the assurance standards that the reporting companies adhere to in the sustainability reporting guidelines.

After this discussion, the students are challenged to make a critical evaluation on the subjects addressed and the session is closed with the presentation of examples and best practices.

\subsection{Challenge Learning Method: The Detailed Development of the Method}

The development of the presentation of the IRA includes information about the IR. In order to properly present the phases of the method a more detailed explanation follows.

In the first phase, we explain that the objective of corporate reporting is to provide useful information to stakeholders so they can make their decisions. This information needs to reflect business dynamics and should include financial reporting that is mandatory and nonfinancial reporting that is voluntary. This evolution leads to a new corporate reporting paradigm called IR.

In the first phase, the professor presents a situation for discussion. Our example is the initiative "\#IWANNABEASPICEGIRL Limited Edition Charity Tee" that the Spice Girls developed to support charities that deal with women's problems. This initiative, despite having charitable objectives, has faced significant problems since the shirts were made in a factory where women earn a lower salary [72]. To make the link with IR, the professor can present a second example of the Enron bankruptcy. The professor then leads a discussion on whether a different reporting model could have dealt with the scandal [73]. To finish the contextualization, the importance of assurance is presented through the example of the Volkswagen's 2015 emissions-rigging scandal, where a problem related to nonfinancial information had large financial implications for the company. The link to Integrated Reporting is made, once it helps organizations to think holistically and to increase reliability and legitimacy with the disclosure of voluntary information such as assurance $[10,11,74,75]$.

In the second phase, after the contextualization, students are challenged to try to find solutions. In this stage, the discussion is open and dependent on the focus of the students.

The third phase details the evolution of corporate reporting. First, the concept of financial reporting is presented in that it is mandatory and that its framework is defined by regulators that produce financial statement standards and the rules that companies must follow. These regulators determine the information that should be provided by companies in their annual reports [76]. Second, nonfinancial reporting is explained as the response to the need of companies to manage their social and environmental responsibilities through their response to internal and external pressures [77] that demonstrates to society and investors the adequacy of their behavior [78]. A sustainability report includes the economic, environmental and social impact caused by the entity's activities [79]. A sustainable strategy enables the organization to add value to investors and to contribute to a sustainable society [80]. In Europe, there is a new legal obligation initially applied to information in 2017. The 2014/95/EU Directive on the disclosure of nonfinancial and diversity information requires European listed companies, insurers, and banks to include social, environmental, and diversity statements in their management report [81,82]. Also, the European Parliament as prepared the proposal for a directive as regards corporate sustainability reporting [83]. Third, the objective is to explain IR and to make the relation with the previous examples. The chronology of events related to IR is as follows: 2004The Princes Accounting for Sustainability Project; 2009-Development of IR, creation of 
the IIRC; 2013-Framework for Integrated Reporting [84-86]; 2021—International <IR> Framework [87]. IR is a concise communication about how an organization's strategy in the context of its external environment leads to the creation of value in the short, medium, and long terms by combining the six capitals (financial, manufacturing, intellectual, human, social and relationship, and natural) with integrated thinking [86].

Now, the professor explains that this evolution in corporate reporting leads to the evolution of auditing. In the beginning, the information audited was only financial and therefore the audit was also only financial. With the disclosure of nonfinancial information in separate reports by companies, part of this information was also certified by independent entities that produced independent assurance statements. Finally, with the companies disclosing IRs, the auditing has grown into an integrated audit opinion. IR is a hybrid practice between financial and sustainability reporting, and because of that, these two worlds must be reconciled to obtain a state of legitimacy. Legitimacy is seen as "a generalized perception that the actions of an entity are desirable, proper, or appropriate within some socially constructed system of norms, values, beliefs, and definitions" [88]. The assurance of sustainability information implicates a higher importance of this information and is associated with the growth of the perceived performance of sustainability [14]. There are different assurance opinions: in the positive assurance opinion the auditors examine evidence and express their opinion about its reliability. It is usually found in the financial reporting [89]. In a negative assurance opinion, which is normally expressed in the nonfinancial reporting [90], the auditors express their opinion by stating that there is no reason to suspect that the information is not reliable [9].

The content of the independent assurance report includes an introduction where the scope and subject matter are presented; the responsibilities of the directors and of the independent assurance provider; the summary of the work performed; the independence; the expertise and limitation of liability, and the conclusions with reasonable or limited assurance. The responsibilities of directors are related to the preparation and presentation of the report; the determination of the company's objectives related to the development of sustainable performance; the identification of material issues; the establishment of internal control systems and performance management, and the selection of the sustainable performance indicators subject to assurance (this aspect may reduce the independence of the assurer [81]. On the other hand, the responsibilities of the independent assurance provider consist of expressing assurance conclusions on the subject matter.

The summary of the work performed by the assurer consists of the interview of managers and senior executives to obtain an understanding of the internal control environment and system and the risk assessment processes relevant to the sustainability report. Further, the assurer should inspect the documentation to corroborate statements by the management and to review the process of determining the material selection of sustainable information. Then it must inspect the supporting documentation and perform analytical procedures on a simple basis to evaluate the data generation and reporting process, to assess the adequacy of significant estimates and judgments in the key performance indicators (KPI), and to evaluate the consistency among the identified sustainability information. Related to expertise, there is the need for a multidisciplinary team. The inherent limitations of nonfinancial information assurance are related to the nature of nonfinancial data. The most seen engagement is limited assurance. In this engagement, the assurer expresses that the conclusions obtained by the work done are only to be used by the directors of the company. The assurer does not assume or accept liability from any other party for the report and the conclusions obtained. In relation to the audit opinion, mostly limited assurance is obtained [91,92].

In a moderate level of assurance, the assurer states that based on the work performed, nothing has come to their attention that causes them to believe that the identified sustainability information is materially misstated. In the case of a reasonable assurance, a high level of assurance is obtained. In this situation, the assurer states that based on the work performed, the identified sustainability information is free from material misstatement. 
In the fourth stage, the students are challenged to discuss the value of assurance, to find and discuss the evolution of the legislation, and to understand why companies disclose independent assurance in their annual report despite the limitations. At this point, the professor can present some examples that may contribute to the discussion of the reasons behind not disclosing the IRA.

Comments on integrated reports related to assurance:

"We voluntarily request independent assurance (.. ) on key accountability data and information to ensure that users, including management, have confidence that our reports are complete, accurate and balanced. Independent assurance also drives improvements and innovation in our management and reporting strategies and practices." [93] (p. 13)

"We value the accuracy and reliability of all information and data in this report, both financial and non-financial. Therefore, assurance for this integrated report is provided.... has reviewed and provided a limited level of assurance on the sustainability information in the chapters." [94] (p. 60)

"As part of the company's commitment to financial, social and environmental responsibility, ... voluntarily includes an assurance report for non-financial reporting in its annual report. The assurance provider reviews whether the non-financial performance information covers aspects deemed to be material and verifies the internal control processes of the information reported responsibility." [95] (p. 43)

"The sustainability aspects of the report have not been externally assured as management do not believe they can justify the cost of such assurance considering the nature of the Group's operations, its current size and the quality and extent of sustainability data published by the Group." [96] (p. 1)

In the fifth phase, the students are challenged to find and discuss the needed professional qualifications and the standards used by assurer companies and by reporting companies. To help the discussion, the professor can explain that the decision related to the professional qualifications to assure sustainability in corporate reports is between being an assurance provider from the accounting profession or non-accounting. The most common providers are those in the audit profession, and mainly in the big four professional firms [91,97]. The Independence Assurance Standards used by the assurers consist mainly of the following standards: ISAE 3000 (International Standard on Assurance Engagements) Assurance Engagements other than Audits or Reviews of Historical Financial Information, issued by the International Auditing and Assurance Standards Board; AA1000 AccountAbility Principles Standard (AA1000 APS); and the AA1000 Assurance Standard (AA1000AS) and International Standard on Quality Control (ISQC). While assurance providers from the accounting profession prefer to use the ISAE 3000, non-accounting providers use the AccountAbility standard AA1000AS [97]. The sustainability reporting guidelines that the companies use to prepare their IRs primarily are: GRI-Global Reporting Initiative; United Nations Global Compact; King Report on Corporate Governance for South Africa; and the AA1000 AccountAbility Principles Standard.

In the sixth stage, students are challenged to make a critical evaluation on the subjects presented. The session is closed with the presentation of examples and best practices.

\subsection{Challenge Learning Method: How to Assess Performance}

The application of the CLM to the IRA has the objective of increasing critical thinking skills. Therefore, an assessment of how well this method performs is important. However, an assessment with adequate measures is a difficult task.

Liu et al. [61] identify three main dimensions of critical thinking: analytical, synthetic, and relevant. Based on these dimensions, we propose the following assessment in Table 2: 
Table 2. Assessment of CLM performance.

\begin{tabular}{|c|c|c|c|c|}
\hline Dimensions & Assessment & Not Meet & Meet & Exceed \\
\hline \multicolumn{5}{|l|}{ Analytical dimensions } \\
\hline \multirow{4}{*}{$\begin{array}{l}\text { Evaluate evidence and its } \\
\text { use }\end{array}$} & $\begin{array}{l}\text { Distinguish between } \\
\text { financial information (FI) } \\
\text { and nonfinancial } \\
\text { information (NFI) }\end{array}$ & $\begin{array}{l}\text { Students' number of } \\
\text { differences is two or more } \\
\text { less than the number } \\
\text { required }\end{array}$ & $\begin{array}{l}\text { Students' number of } \\
\text { differences is one less than } \\
\text { the number required }\end{array}$ & $\begin{array}{l}\text { Students identify the } \\
\text { minimum number of } \\
\text { differences }\end{array}$ \\
\hline & $\begin{array}{l}\text { Identify the level of } \\
\text { reliability of the } \\
\text { information disclosed }\end{array}$ & $\begin{array}{l}\text { Students are not capable } \\
\text { of distinguishing the } \\
\text { different levels of } \\
\text { reliability }\end{array}$ & $\begin{array}{l}\text { Students distinguish the } \\
\text { level of reliability of the } \\
\text { information disclosed }\end{array}$ & $\begin{array}{l}\text { Students distinguish the } \\
\text { level of reliability and } \\
\text { identify the causes }\end{array}$ \\
\hline & $\begin{array}{l}\text { Identify the role of the } \\
\text { audit in the FI, NFI, and IR }\end{array}$ & $\begin{array}{l}\text { Students do not } \\
\text { understand the role of } \\
\text { audit }\end{array}$ & $\begin{array}{l}\text { Students understand the } \\
\text { role of audit only for FI }\end{array}$ & $\begin{array}{l}\text { Students understand the } \\
\text { role for FI, NFI, and IR }\end{array}$ \\
\hline & $\begin{array}{l}\text { Consider potential } \\
\text { motivations for providing } \\
\text { truthful or misleading } \\
\text { information }\end{array}$ & $\begin{array}{l}\text { Students do not recognise } \\
\text { the existence of potential } \\
\text { motivations for providing } \\
\text { truthful information }\end{array}$ & $\begin{array}{l}\text { Students recognise } \\
\text { potential motivations for } \\
\text { providing truthful } \\
\text { information, but only } \\
\text { partially }\end{array}$ & $\begin{array}{l}\text { Students recognise all } \\
\text { potential motivations for } \\
\text { providing truthful or } \\
\text { misleading information }\end{array}$ \\
\hline \multirow{3}{*}{$\begin{array}{l}\text { Analyse and evaluate } \\
\text { arguments }\end{array}$} & $\begin{array}{l}\text { Discuss the advantages } \\
\text { and disadvantages of IR }\end{array}$ & $\begin{array}{l}\text { Students' number of } \\
\text { advantages and } \\
\text { disadvantages is two or } \\
\text { more less than required }\end{array}$ & $\begin{array}{l}\text { Students' number of } \\
\text { advantages and } \\
\text { disadvantages is one less } \\
\text { than required }\end{array}$ & $\begin{array}{l}\text { Students identify the } \\
\text { minimum number of } \\
\text { advantages and } \\
\text { disadvantages }\end{array}$ \\
\hline & $\begin{array}{l}\text { Discuss the advantages } \\
\text { and disadvantages of IRA }\end{array}$ & $\begin{array}{l}\text { Students' number of } \\
\text { advantages and } \\
\text { disadvantages is two or } \\
\text { more less than required }\end{array}$ & $\begin{array}{l}\text { Students' number of } \\
\text { advantages and } \\
\text { disadvantages is one less } \\
\text { than required }\end{array}$ & $\begin{array}{l}\text { Students identify the } \\
\text { minimum number of } \\
\text { advantages and } \\
\text { disadvantages }\end{array}$ \\
\hline & $\begin{array}{l}\text { Distinguish valid from } \\
\text { invalid arguments, } \\
\text { presented in real situations }\end{array}$ & $\begin{array}{l}\text { Students analyse more } \\
\text { invalid than valid } \\
\text { arguments }\end{array}$ & $\begin{array}{l}\text { Students analyse more } \\
\text { valid than invalid } \\
\text { arguments }\end{array}$ & $\begin{array}{l}\text { Students analyse only } \\
\text { valid arguments }\end{array}$ \\
\hline \multicolumn{5}{|l|}{ Synthetic dimensions } \\
\hline \multirow[t]{2}{*}{$\begin{array}{l}\text { Understand implications } \\
\text { and consequences }\end{array}$} & $\begin{array}{l}\text { Draw or recognize } \\
\text { conclusions from cases } \\
\text { provided }\end{array}$ & $\begin{array}{l}\text { Students do not recognise } \\
\text { any conclusions }\end{array}$ & $\begin{array}{l}\text { Students recognise some } \\
\text { but not the majority of the } \\
\text { conclusions }\end{array}$ & $\begin{array}{l}\text { Students recognise the } \\
\text { majority of the } \\
\text { conclusions }\end{array}$ \\
\hline & $\begin{array}{l}\text { Identify the need of } \\
\text { professional qualifications } \\
\text { and standards for the IRA }\end{array}$ & $\begin{array}{l}\text { Students do not identify } \\
\text { the need of professional } \\
\text { qualifications and } \\
\text { standards }\end{array}$ & $\begin{array}{l}\text { Students identify the need } \\
\text { of professional } \\
\text { qualifications or standards } \\
\text { for the IRA }\end{array}$ & $\begin{array}{l}\text { Students identify the need } \\
\text { of both professional } \\
\text { qualifications and } \\
\text { standards for the IRA }\end{array}$ \\
\hline \multirow[t]{2}{*}{$\begin{array}{l}\text { Develop sound and valid } \\
\text { arguments }\end{array}$} & $\begin{array}{l}\text { Develop valid and sound } \\
\text { arguments }\end{array}$ & $\begin{array}{l}\text { Students develop valid } \\
\text { and sound arguments only } \\
\text { in one phase }(2,4,5 \text { or } 6)\end{array}$ & $\begin{array}{l}\text { Students develop valid } \\
\text { and sound arguments in } \\
\text { two phases }(2,4,5 \text { or } 6)\end{array}$ & $\begin{array}{l}\text { Students develop valid } \\
\text { and sound arguments in } \\
\text { three or four phases }(2,4 \text {, } \\
5 \text { or } 6)\end{array}$ \\
\hline & $\begin{array}{l}\text { Select or provide } \\
\text { appropriate evidence }\end{array}$ & $\begin{array}{l}\text { Students do not select and } \\
\text { provide appropriate } \\
\text { evidence }\end{array}$ & $\begin{array}{l}\text { Students select } \\
\text { appropriate evidence but } \\
\text { do not communicate } \\
\text { adequately }\end{array}$ & $\begin{array}{l}\text { Students select } \\
\text { appropriate evidence and } \\
\text { communicate adequately }\end{array}$ \\
\hline \multicolumn{5}{|c|}{ Relevant to analytical and synthetic dimensions } \\
\hline $\begin{array}{l}\text { Understand causation and } \\
\text { explanation }\end{array}$ & $\begin{array}{l}\text { Evaluate the consequences } \\
\text { of inexistence of assurance } \\
\text { for IR }\end{array}$ & $\begin{array}{l}\text { Students' explanations of } \\
\text { the consequences are } \\
\text { incomplete and/or } \\
\text { contain two or more } \\
\text { inappropriate } \\
\text { consequences }\end{array}$ & $\begin{array}{l}\text { Students' explanations of } \\
\text { the consequences are } \\
\text { partially incomplete } \\
\text { and/or contain one } \\
\text { inappropriate } \\
\text { consequence }\end{array}$ & $\begin{array}{l}\text { Students provide a } \\
\text { complete explanation of } \\
\text { the consequences }\end{array}$ \\
\hline
\end{tabular}

\section{Discussion}

Today, society is awakening to sustainable development, young people are developing a different conscience, companies are changing the way of doing corporate reporting and auditing, and investors are switching their investment decisions to sustainable companies. Thus, universities must change to embrace the sustainability movement, present solutions, motivate and challenge this generation even more, and use this force to increase the knowledge on new practices such as IR and IRA.

We have identified four theories that are used more often in relation to the subjects of IR, Assurance and Education. First, we have seen that the central thesis based on agency theory is that independent audit detects, or even reduces, fraudulent reporting 
practices [37] and that once sustainability reports are aimed not just to shareholders but to a variety of stakeholders, the increase of sustainability reporting challenges the effectiveness of agency theory in supporting the motivation for the disclosure of this information [38]. In light of institutional theory, we have seen that EU directives or recommendations, exert a pressure that is influencing companies towards SR assurance, and that regulation on sustainability reporting in general, determines the institutional structures and plays an important role in the development of sustainability reporting [43]. Also, assurance appears because of coercive, mimetic or normative pressures and auditors employ normative and/or coercive pressures [33]. Legitimacy theory suggests that companies need to disclose financial and sustainability information to report the performance of socially responsible companies with the aim of such data being verified externally [45] and that sustainability assurance allows legitimation of the company to ensure higher transparency and improving sustainable business to advance accounting for a sustainable development [46]. Lastly, companies should act responsibly towards their stakeholders about non-financial impacts of their operations, and legitimate company stakeholders require CSR disclosures to be independently assured $[48,49]$.

The conclusions are coherent with other studies that indicate that the widespread adoption of IR requires significant changes in practitioners and in accounting curricula at universities that include: reporting on wider performance metrics and not only on external financial reporting; a prospective analysis instead of retrospective; a long-term outlook instead of short-term; a focus on the strategic rather than on the operational or transactional; and to produce and analyze qualitative information that complements the quantitative and audited information [19]. Likewise, the need to find and develop learning methods to increase the diffusion of IR and IRA is justified through previous research which states that academics can make a relevant contribution in the dissemination of IR through education, that business schools are currently not providing sufficient educational programs on IR and there is a need for educational programs to fill that void, [18]; that accounting curriculum may have to change in order to respond to the move towards IR and to proper educate current and future report preparers and stakeholders [20]. Also, Adhariani and de Villiers [20], have found that accounting academics, who may be expected to be more informed regarding new developments in corporate reporting, have no better knowledge of IR than other stakeholders; therefore, it is crucial to provide specified learning models to teach IR and IRA. We may add that accounting and auditing students need to be exposed to different types of assurance services and reporting frameworks and to be trained in those reporting and assurance developments [22].

In the light of the current IRA, we can add to these developments the need to assure audit compliance for financial and sustainability information.

In response to the research questions:

RQ1: What are the learning practices used to teach IR and IRA?

The other studies on learning practices that focused on teaching IR and IRA are scarce, as shown in Section 2. We found some studies that focus on sustainability and used different learning practices, such as problem-based learning [58-60], project-based learning [53,61], and experiential learning [55,62,63]; but the norm continues to be a passive pedagogy through lecturing and solving problems on the blackboard. This gap in the literature about learning practices for IRA creates the opportunity to develop this study.

According to previous studies, the research has found that experiential learning, with the use of challenges to teach, is an adequate pedagogy for teaching sustainability and IR. This method requires students to ask their own questions instead of presenting the question to the students. This pedagogy is mostly appropriate for teaching concepts when there is a set of different choices with many dimensions to the skills and when the situation is new and uncertain and the knowledge is context-specific $[63,71]$. The key to effective learning is the capability to think, instead of just doing. By challenging students, professors are helping them to always look for the best solution and to pay attention to new possibilities. 
It is through the presentation of challenges that professors may help students to go from doing to thinking.

RQ2: How can the challenge learning method be used to teach IRA?

The challenge learning method is an adequate method to teach IRA for four main reasons. First, the IRA is a topic where there are no absolute steps but only a set of possible choices. Second, the IRA requires many dimensions in skills and an expert may not make all the choices explicit. Third, the knowledge is context specific, and fourth, the IRA is relatively new and uncertain. In Section 4.2, we identify the phases of the method, and in Section 4.3 we present a detailed development of the method. Previous studies have found that bringing sustainability issues to the higher education curricula may lead to several positive outcomes related to attitudes and behavior [55], but it has also been found that the inclusion of this topic in accounting education is still uncoordinated and sporadic [53,54]. Furthermore, it has been noted that there are some resistances from academic staff in changing the teaching focus such as the combination of qualitative and quantitative information, to thinking long-term instead of only short-term, to teach strategy instead of only transactional $[19,56]$. Therefore, by providing professors with a tool to introduce IR and IRA, the proposed method contributes for the consolidation of the inclusion of sustainability issues in traditional accounting curricula. Moreover, challenge learning method uses experiential learning pedagogy that has been considered suitable for teaching sustainability and IR $[63,65-67,71]$ and has been previously used to teach sustainability issues $[62,68]$.

RQ3: What indicators can be used to assess the performance of the challenge learning method when it is applied to the IRA?

Based on Liu et al. [61], we identified a model that can be used to assess the performance of the challenge learning method. The advantage of using this type of assessment model is that it forces the professor to clearly identify the learning objectives for each challenge. Consequently, the professor can provide more specific feedback to students on their abilities and identify which phases the students performed adequately and which phases must be improved.

The challenge learning method can be applied with different levels of detail that depend on the available time. The minimum purpose is to develop the curiosity of the students regarding the subjects of IRA, IR, and sustainability. This is applicable to a presentation in one single session. The intermediate application is related to the possibility to introduce the subjects with the use of two to four sessions. In this situation, it would be possible to develop in a more detailed way the subjects instead of only briefly presenting them so that students may understand the concepts and the relation between them. With the increase in the interest in the presented subjects, it may be possible to develop the challenge learning method in one full module. If this possibility occurs, it can be used to more deeply teach the subjects in order that the student may not only understand the concepts but also be prepared to implement in practice the subjects of IR, IRA, and sustainability reporting.

On the sequence of the use of the challenge learning method in the presentations of the IRA to undergraduate and post-graduate degrees, it has been possible to assist in increasing the participation of the students in developing the academic research on the subjects of IRA, IR, and sustainability report.

One limitation of this study is the absence of tests on the proposed method other than the teaching experience of the authors [26]. On the sequence of the exposed, one possible future avenue is to interview or to question the students that have participated in said classes to confirm the effectiveness of the proposed method. As the inclusion of IR and IRA at the universities is still in its first steps, further studies on this implementation may be needed. Considering that this is a new research area, it would be interesting to verify if professors at the universities are prepared to lecture on the subject of IRA. Regarding the proposed method, the challenge learning method may be generalized in order to be applicable to wider subjects. Finally, another study to conduct may be the application of 
the proposed method to auditing and corporate reporting to find if it has improved the learning outcomes in these subjects.

\section{Concluding Remarks}

The conclusions are coherent with previous studies since the widespread adoption of IR requires significant changes not only in practitioners but also in higher education accounting curricul, a such as a focus on the strategic; a long-term outlook; a prospective analysis; reporting on wider performance metrics instead of only financial reporting; and to disclose and analyze qualitative information that complements the quantitative information [19]. The diffusion of IR and the increased disclosure of IRA has led to a change in corporate reporting and auditing practices that has brought about different needs for the knowledge and capacities of employees. The convergence of the evolution in corporate reporting and in society has preceded universities to evolve and to change the curricula of post-graduate and undergraduate degrees. To enhance their role in society, universities need to be forward-looking and to educate students with innovative ideas, subjects, methods, and capabilities.

According to Perego et al. [18], academics can make a relevant contribution in the dissemination of IR through education and that there is a need for additional educational programs on IR. Adhariani e de Villiers [20], have found that accounting academics had no better knowledge of IR than other stakeholder classes, being crucial to provide specified learning models to teach IR and IRA. Maroun [22], express that accounting and auditing students need to be subjected and trained to different types of assurance services and reporting frameworks. Therefore, universities need to be aware of these changes in order to properly prepare their students and to increase the possibilities of a better future and better jobs for the workforce.

From society's point of view, especially younger people's, the greater concerns about sustainability, environment, and social development have led to the demand for the existence of these subjects when looking to the future and particularly in the moment when they must decide at which institution to get their degree. Consequently, there is the need to find and develop learning methods to increase the diffusion of IR and IRA.

In this light, we intend for the proposed challenge learning method to provide universities and professors with a tool that may allow the increase in the diffusion of the subjects of IR and IRA in post-graduate and undergraduate degrees. The presentation of these topics as several challenges allows students to be part of the learning process and to conduct the subjects from the most interesting perspective, according to their previous experience and knowledge. The discussion of well-diffused examples and situations increases the curiosity of the students and, therefore, works as leverage in the acquisition of new ideas and concepts. In this way, the learning process is natural and more productive.

The result of the study consists of a method that can increase accounting academics knowledge of IR and IRA and motivate students to study these emerging accounting practices.

This study has several contributions. First, the extant literature on IR, IRA and Education is scarce. Second, our research contributes to the use of appropriate teaching methods to IR and IRA. Third, our study contributes to the dissemination of IR and IRA in education by providing a better connection between the universities and the best practices of corporate reporting and auditing. Therefore, this study leads to an increase in the connection among higher education institutions, professors, students, practitioners, auditors, regulators, standard setters, and society in general.

The theoretical implications consist of the identification of teaching methodologies used for the teaching of sustainability and the presentation of a proposal for a higher education methodology appropriate to GFRI. The practical implication of this study is related to the implementation of the transmission of knowledge in higher education.

Author Contributions: Conceptualization, M.A.B.R. and A.I.M.; methodology, M.A.B.R. and A.I.M.; investigation, M.A.B.R. and A.I.M.; writing-original draft preparation, M.A.B.R. and A.I.M.; writing- 
review and editing, M.A.B.R. and A.I.M.; visualization, M.A.B.R. and A.I.M. Both authors have read and agreed to the published version of the manuscript.

Funding: The authors gratefully acknowledge financial support from FCT-Fundação para a Ciência e Tecnologia (Portugal), national funding through research grant UIDB/04521/2020.

Conflicts of Interest: The authors declare no conflict of interest.

\section{References}

1. Camilleri, M.A. Corporate sustainability and responsibility: Creating value for business, society and the environment. Asian J. Sustain. Soc. Responsib. 2017, 2, 59-74. [CrossRef]

2. Park, A.; Ravenel, C. Integrating sustainability into capital markets: Bloomberg LP And ESG's quantitative legitimacy. J. Appl. Corp. Financ. 2013, 25, 62-67.

3. Husted, B.W.; de Sousa-Filho, J.M. The impact of sustainability governance, country stakeholder orientation, and country risk on environmental, social, and governance performance. J. Clean. Prod. 2017, 155, 93-102. [CrossRef]

4. United Nations. Transforming Our World: The 2030 Agenda for Sustainable Development; United Nations: New York, NY, USA, 2015.

5. Kühne, R.W. Climate Change: The Science Behind Greta Thunberg and Fridays for Future; Rainer W. Kühne: Braunschweig, Germany, 2019.

6. Wahlström, M.; Sommer, M.; Kocyba, P.; de Vydt, M.; De Moor, J.; Davies, S.; Buzogany, A. Protest for a Future: Composition, Mobilization and Motives of the Participants in Fridays for Future Climate Protests on 15 March 2019 in 13 European Cities; Keele University: Staffordshire, UK, 2019.

7. Druckman, P. Integrated Reporting: A New Governanee Tool. Corp. Board 2014, 35, 6-11.

8. Eccles, R.G.; Krzus, M.P.; Rogers, J.; Serafeim, G. The Need for Sector-Specific Materiality and Sustainability Reporting Standards. Appl. Corp. Financ. 2012, 24, 65-71. [CrossRef]

9. Gary, M.C.; Fagerström, A.; Hassel, L.G. Accounting for Sustainability: What Next? A Research Agenda. Ann. Fac. Econ. 2011, 1, 97-111.

10. Pflugrath, G.; Roebuck, P.; Simnett, R. Impact of Assurance and Assurer's Professional Affiliation on Financial Analysts' Assessment of Credibility of Corporate Social Responsibility Information. Audit. A J. Pract. Theory 2011, 30, 239-254. [CrossRef]

11. de Villiers, C.; Rinaldi, L.; Unerman, J. Integrated Reporting: Insights, gaps and an agenda for future research. Account. Audit. Account. J. 2014, 27, 1042-1067. [CrossRef]

12. Adams, C.A. The International Integrated Reporting Council: A call to action. Crit. Perspect. Account. 2015, 27, 23-28. [CrossRef]

13. Dumay, J.; Bernardi, C.; Guthrie, J.; Demartini, P. Integrated reporting: A structured literature review. Account. Forum 2016, 40, 166-185. [CrossRef]

14. Reimsbach, D.; Hahn, R.; Gürtürk, A. Integrated Reporting and Assurance of Sustainability Information: An Experimental Study on Professional Investors' Information Processing. Eur. Account. Rev. 2018, 27, 559-581. [CrossRef]

15. IIRC. Assurance on IR: An Introduction to the Discussion; IIRC: London, UK, 2014; pp. 1-9.

16. IIRC. Assurance on $<I R>$ Overview of Feedback and Call to Action; IIRC: London, UK, 2015.

17. IFAC and IIRC Accelerating Integrated Reporting Assurance in the Public Interest. IFAC and the IIRC Support Pathway to Integrated Reporting Assurance. 2020. Available online: http//www.ifac.org/knowledge-gateway/preparing-future-readyprofessionals/publications/accelerating-integrated-reporting-assurance-pu (accessed on 30 July 2021).

18. Perego, P.; Kennedy, S.; Whiteman, G. A lot of icing but little cake? Taking Integrated Reporting forward. J. Clean. Prod. 2016, 136, 53-64. [CrossRef]

19. Owen, G. Integrated Reporting: A Review of Developments and their Implications for the Accounting Curriculum. Account. Educ. 2013, 22, 340-356. [CrossRef]

20. Adhariani, D.; de Villiers, C. Integrated reporting: Perspectives of corporate report preparers and other stakeholders. Sustain. Account. Manag. Policy J. 2019, 10, 126-156. [CrossRef]

21. Dolce, V.; Emanuel, F.; Cisi, M.; Ghislieri, C. The soft skills of accounting graduates: Perceptions versus expectations. Account. Educ. 2019, 29, 57-76. [CrossRef]

22. Maroun, W. Exploring the rationale for integrated report assurance. Account. Audit. Account. J. 2019, 32, 1826-1854. [CrossRef]

23. Brown, V.L.; Kohlbeck, M.J. Providing Assurance for Sustainability Reports: An Instructional Case. Issues Account. Educ. 2017, 32, 95-102. [CrossRef]

24. Johnson, L.F.; Smith, R.S.; Smythe, J.T.; Varon, R.K. Challenge-Based Learning An Approach for Our Time; The New Media Consortium: Austin, TX, USA, 2009; pp. 1-38.

25. Feldon, D.F.; Peugh, J.; Timmerman, B.E.; Maher, M.A.; Hurst, M.; Strickland, D.; Stiegelmeyer, C. Graduate students' teaching experiences improve their methodological research skills. Science 2011, 333, 1037-1039. [CrossRef]

26. Creel, T.; Paz, V. Teaching Sustainability in an Accounting Classroom. Discourse Commun. Sustain. Educ. 2018, 9, 79-85. [CrossRef]

27. Brown, J.; Dillard, J. Integrated reporting: On the need for broadening out and opening up. Account. Audit. Account. J. 2014, 27, 1120-1156. [CrossRef]

28. Frías-Aceituno, J.V.; Rodríguez-Ariza, L.; García-Sánchez, I.M. Is integrated reporting determined by a country's legal system? An exploratory study. J. Clean. Prod. 2013, 44, 45-55. [CrossRef] 
29. Dumay, J.; Xi Dai, T.M. Integrated thinking as an organisational cultural control? Presented at the Critical Perspectives on Accounting Conference, Toronto, ON, Canada, 7-9 July 2014.

30. Simnett, R.; Huggins, A.L. Integrated reporting and assurance: Where can research add value? Sustain. Account. Manag. Policy J. 2015, 6, 29-53. [CrossRef]

31. Gerwanski, J. Does it pay off? Integrated reporting and cost of debt: European evidence. Corp. Soc. Responsib. Environ. Manag. 2020, 27, 2299-2319. [CrossRef]

32. Reimsbach, D.; Schiemann, F.; Hahn, R.; Schmiedchen, E. In the Eyes of the Beholder: Experimental Evidence on the Contested Nature of Materiality in Sustainability Reporting. Organ. Environ. 2020, 33, 624-651. [CrossRef]

33. Briem, C.R.; Wald, A. Implementing third-party assurance in integrated reporting: Companies' motivation and auditors' role. Account. Audit. Account. J. 2018, 31, 1461-1485. [CrossRef]

34. Brown-Liburd, H.; Zamora, V.L. The Role of Corporate Social Responsibility (CSR) Assurance in Investors' Judgments When Managerial Pay is Explicitly Tied to CSR Performance. Audit. A J. Pract. Theory 2015, 34, 75-96. [CrossRef]

35. Maroun, W. Does external assurance contribute to higher quality integrated reports? J. Account. Public Policy 2019, $38,106670$. [CrossRef]

36. Maroun, W. A Conceptual Model for Understanding Corporate Social Responsibility Assurance Practice. J. Bus. Ethics 2018, 161, 187-209. [CrossRef]

37. Haji, A.; Anifowose, M. Audit Committee and Integrated Reporting Practice: Does Internal Assurance Matter? Manag. Audit. J. 2016, 31, 915-948. [CrossRef]

38. Wang, R.; Zhou, S.; Wang, T. Corporate Governance, Integrated Reporting and the Use of Credibility-enhancing Mechanisms on Integrated Reports. Eur. Account. Rev. 2020, 29, 631-663. [CrossRef]

39. Vaz, N.; Fernandez-Feijoo, B.; Ruiz, S. Integrated reporting: An international overview. Bus. Ethics A Eur. Rev. 2016, 25, 577-592. [CrossRef]

40. Hahn, R.; Kühnen, M. Determinants of sustainability reporting: A review of results, trends, theory, and opportunities in an expanding field of research. J. Clean. Prod. 2013, 59, 5-21. [CrossRef]

41. Rivera-Arrubla, Y.A.; Zorio-Grima, A.; García-Benau, M.A. Integrated reports: Disclosure level and explanatory factors. Soc. Responsib. J. 2017, 13, 155-176. [CrossRef]

42. Wild, S.; van Staden, C. Integrated Reporting: Initial analysis of early reporters-An Institutional Theory approach. In Proceedings of the 7th Asia Pacific Interdisciplinary Accounting Research Conference, Kobe, Japan, 26-28 July 2013; pp. 1-39.

43. Fernandez-Feijoo, B.; Romero, S.; Ruiz, S. Multilevel Approach to Sustainability Report Assurance Decisions. Aust. Account. Rev. 2015, 25, 75. [CrossRef]

44. Abernathy, J.; Stefaniak, C.; Wilkins, A.; Olson, J. Literature review and research opportunities on credibility of corporate social responsibility reporting. Am. J. Bus. 2017, 32, 24-41. [CrossRef]

45. Zyznarska-Dworczak, B. Determinants for the Development of non-Financial Reporting and its External Verification in the Light of Accounting Theory and Practice. Stud. Oeconomica Posnaniensia 2017, 5, 136-149. [CrossRef]

46. Zyznarska-Dworczak, B.; Fijałkowska, J. Sustainability assurance in the light of the legitimacy theory. Przedsiębiorczość Zarzadzanie 2018, 19, 395-408.

47. Beske, F.; Haustein, E.; Lorson, P.C. Materiality analysis in sustainability and integrated reports. Sustain. Account. Manag. Policy J. 2020, 11, 162-186. [CrossRef]

48. Freeman, R.E. The Politics of Stakeholder Theory: Some Future Directions. Bus. Ethics Q. 1994, 409-421. [CrossRef]

49. Ackers, B. An exploration of internal audit's corporate social responsibility role-Insights from South Africa. Soc. Responsib. J. 2016, 12, 719-739. [CrossRef]

50. Zyznarska-Dworczak, B. Accounting theories towards non-financial reporting. Stud. Ekon. 2018, 356, 157-169.

51. Kräusche, K.; Pilz, S. Integrated sustainability reporting at HNE Eberswalde-A practice report. Int. J. Sustain. High. Educ. 2017, 19, 291-312. [CrossRef]

52. Dumay, J.; Adams, M. The Learning Journey of IC Missionaries: Intuition, Control and Value Creation. Electron. J. Knowl. Manag. 2014, 12, 135-143.

53. Hazelton, J.; Haigh, M. Incorporating sustainability into accounting curricula: Lessons learnt from an action research study. Account. Educ. 2010, 19, 159-178. [CrossRef]

54. Gomes, S.F.; Jorge, S.; Eugénio, T. Teaching sustainable development in business sciences degrees: Evidence from Portugal. Sustain. Account. Manag. Policy J. 2021, 12, 611-634. [CrossRef]

55. Lee, W.E.; Birkey, R.N.; Patten, D.M. Exposing Students to Environmental Sustainability in Accounting: An Analysis of Its Impacts in a US Setting. Soc. Environ. Account. J. 2017, 37, 81-96. [CrossRef]

56. Mburayi, L.; Wall, T. Sustainability in the professional accounting and finance curriculum: An exploration. High. Educ. Ski. Work. Learn. 2018, 8, 291-311. [CrossRef]

57. Wong, J.; Pippin, S.; Weber, J.; Bergner, J. The Inclusion of Sustainability in the Accounting Curriculum. CPA J. 2016, 86, 44.

58. Bouten, L.; Hoozée, S. Challenges in Sustainability and Integrated Reporting. Issues Account. Educ. 2015, 30, 373-381. [CrossRef]

59. Stubbs, W.; Cocklin, C. Teaching sustainability to business students: Shifting mindsets. Int. J. Sustain. High. Educ. 2008, 9, 206-221. [CrossRef] 
60. Wyness, L.; Dalton, F. The value of problem-based learning in learning for sustainability: Undergraduate accounting student perspectives. J. Account. Educ. 2018, 45, 1-19. [CrossRef]

61. Liu, H.H.; Wang, Q.; Su, Y.S.; Zhou, L. Effects of project-based learning on teachers' information teaching sustainability and ability. Sustainability 2019, 11, 5975. [CrossRef]

62. Collins, E.; Kearins, K. Exposing students to the potential and risks of stakeholder engagement when teaching sustainability: A classroom exercise. J. Manag. Educ. 2007, 31, 521-540. [CrossRef]

63. Young, M.; Warren, D. Lee Encouraging the development of critical thinking skills in the introductory accounting courses using the challenge problem approach. Issues Account. Educ. 2011, 26, 859-881. [CrossRef]

64. Hardin, R.; Bhargava, A.; Bothner, C.; Browne, K.; Kusano, S.; Golrokhian, A.; Agrawal, A. Towards a revolution in sustainability education: Vision, architecture, and assessment in a case-based approach. World Dev. Perspect. 2016, 1, 58-63. [CrossRef]

65. Vygotsky, L.S. Mind in Society: The Development of Higher Psychological Processes; Harvard University Press: Cambridge, MA, USA, 1978.

66. Frisk, E.; Larson, K.L. Educating for Sustainability: Competencies \& Practices for Transformative Action. J. Sustain. Educ. 2011, 2, $1-20$.

67. Apple Challenge Based Learning A Classroom Guide; Apple Inc.: Cupertino, CA, USA, 2010. Available online: https://images.apple. com/education/docs/CBL_Classroom_Guide_Jan_2011.pdf (accessed on 15 November 2020).

68. Sulkowski, A.J.; Kowalczyk, W.; Ahrendsen, B.L.; Kowalski, R.; Majewski, E. Enhancing Sustainability Education through Experiential Learning of Sustainability Reporting. Int. J. Sustain. High. Educ. 2020, 21, 1233-1247. [CrossRef]

69. Hansen, J.D. Using Problem-Based Learning in Accounting. J. Educ. Bus. 2006, 81, 221-224. [CrossRef]

70. Stanley, T.; Marsden, S. Problem-based learning: Does accounting education need it? J. Account. Educ. 2012, 30, 267-289. [CrossRef]

71. Leonard, D.; Swap, W. Deep Smarts. Harv. Bus. Rev. 2004, 30, 157-169. [CrossRef]

72. The Sun INHUMAN 'Spice Girls' Shocked and Appalled; The Sun: London, UK, 2019.

73. ICAEW. Developments in New Reporting Models. Financial Report. Faculty; ICAEW: London, UK, 2009.

74. Eccles, R.G.; Krzus, M.P. One Report-Integrated Reporting For A Sustainable Strategy. Financ. Exec. 2010 , $26,28-32$.

75. Eccles, R.G.; Krzus, M.P.; Watson, L.A. Integrated Reporting Requires Integrated Assurance. In Effective Auditing for Corporates: Key Developments in Practice and Procedures; Oringel, J., Ed.; Bloomsbury Information Ltd.: London, UK, 2012 ; pp. 161-178. [CrossRef]

76. IASB. The Conceptual Framework for Financial Reporting, Technical Summary. International Financial Standards 1-3. 2014. Available online: https:/ / www.iasplus.com/en/standards/other/framework (accessed on 1 September 2021).

77. Klovienè, L.; Speziale, M.T. Sustainability Reporting as a Challenge for Performance Measurement: Literature Review. Econ. Bus. 2014, 26, 44. [CrossRef]

78. Odriozola, M.A.; Saánchez, J.A.C.; Etxeberria, I.Á. Divulgación de información sobre corrupción: Empresas del ibex 35*. Rev. Contab. Account. Rev. 2012, 15, 59-90. [CrossRef]

79. Stubbs, W.; Higgins, C. Integrated Reporting and internal mechanisms of change. Account. Audit. Account. J. 2014, 27, 1068-1089. [CrossRef]

80. Eccles, R.G.; Serafeim, G. A table of two stories: Sustainability and the Quarterly Earnings Call. Appl. Corp. Financ. 2013, 25, 8-19. [CrossRef]

81. Corrado, M.; Demartini, P.; Dumay, J. Assurance on Integrated Reporting: A Critical Perspective; Springer International Publishing: New York, NY, USA, 2019; pp. 199-217.

82. EU Commission. Directive 2014/95/EU of the European Parliament and of the Council of 22 October 2014 amending Directive 2013/34/EU as regards disclosure of non-financial and diversity information by certain large undertaking and groups. Off. J. Eur. Union. 2014, 330, 1-9.

83. EU Commission. Proposal for a Directive of the European Parliament and of the Council amending Directive 2013/34/EU, Directive 2004/109/EC, Directive 2006/43/EC and Regulation (EU) No 537/2014, as regards corporate sustainability reporting. Off. J. Eur. Union. 2021, 2021, 1-65.

84. Busco, C.; Frigo, M.L.; Quattrone, P.; Riccaboni, A. Leading Practices in Integrated Reporting (Cover Story). Strateg. Financ. 2014, 2014, 23-32.

85. Fried, A.; Holtzman, M.P.; Mest, D. IR the new annual Report for the 21st century. Financ. Exec. 2014, $2014,24-31$.

86. IIRC. The International IR Framework; IIRC: London, UK, 2013; p. 37.

87. IIRC. International <IR> Framework; IIRC: London, UK, 2021; p. 58.

88. Suchman, M.C. Managing Legitimacy: Strategic and Institutional Approaches. Acad. Manag. Rev. 1995, 20, 571. [CrossRef]

89. Eccles, R.G.; Saltzman, D. Achieving Sustainability Through Integrated Reporting. Stanf. Soc. Innov. Rev. 2011, 3, 56-61.

90. Eccles, R.G.; Krzus, M.P.; Ribot, S. The Integrated Reporting Movement: Meaning, Momentum, Motives and Materiality. J. Clean. Prod. 2015, 86, 285-288.

91. Canning, M.; O’Dwyer, B.; Georgakopoulos, G. Processes of auditability in sustainability assurance-The case of materiality construction. Account. Bus. Res. 2019, 49, 1-27. [CrossRef]

92. Gomes, S.F.; Eugénio, T.C.P.; Branco, M.C. Sustainability reporting and assurance in Portugal. Corp. Gov. Int. J. Bus. Soc. 2015, 15, 281-292. [CrossRef] 
93. Vancity Vancity 2011 Annual Report; Vancity: Vancouver, BC, Canada, 2012.

94. ING. ING Group Annual Report 2015: A Step Ahead; ING Group: Amsterdam, The Netherlands, 2016; p. 442.

95. Novo Nordisk. Novo Nordisk Annual Report 2011; Novo Nordisk: Bagsværd, Denmark, 2012.

96. Santova. Annual Integrated Report; Santova: Durban, South Africa, 2015.

97. Farooq, M.B.; de Villiers, C. The shaping of sustainability assurance through the competition between accounting and nonaccounting providers. Account. Audit. Account. J. 2019, 32, 307-336. [CrossRef] 